\title{
The Relationship between Family History of Type 2 Diabetes Mellitus and Knowledge, Attitude, and Practice Regarding Type 2 Diabetes Mellitus among Medical Students
}

\author{
Jilan Fachirah ${ }^{1}$, Mutiara Indah Sari ${ }^{2 *}$ \\ ${ }^{1}$ Department of Medical Education, Faculty of Medicine, Universitas Sumatera Utara, Medan, Indonesia; ${ }^{2}$ Department of \\ Biochemistry, Faculty of Medicine, Universitas Sumatera Utara, Medan, Indonesia
}

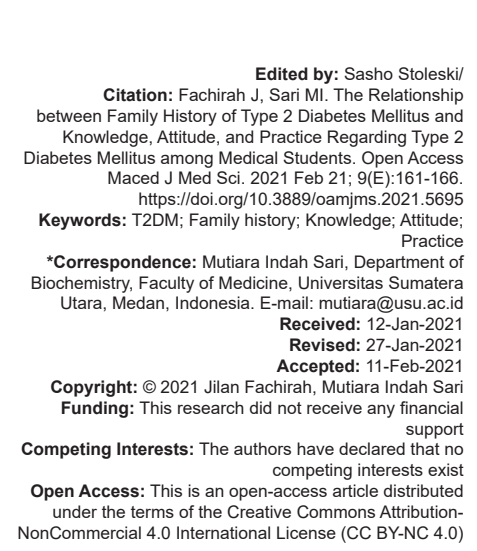

\section{Introduction}

Diabetes mellitus (DM) is a metabolic disorder with symptoms of increased blood glucose levels because pancreatic cells cannot synthesis and/or secrete insulin. Based on the International Diabetes Federation, in 2019 in the world, the prevalence of the adult population aged 20-79 years suffering from diabetes reaches 463 million people and is expected to increase to 700 million people in 2045 [1]. DM is classified into two main types, namely, Type $1 \mathrm{DM}$ and Type 2 DM (T2DM), where it is estimated that $90 \%$ of all DM patients are T2DM. For many years, T2DM has only been seen in adults, but, nowadays, it has started to occur at a young age [2].

The occurrence of T2DM is influenced by various risk factors. T2DM risk factors are divided into non-modifiable and modifiable. The non-modifiable risk factors are age and genetic (hereditary), while the factors that can be modified are the behavior of wrong diet, inadequate physical activity, obesity, stress, etc. Behavior in the domain of knowledge, attitudes, and practice toward risk factors and prevention of a disease can influence a person to suffer from the disease [3], [4], [5].

The previous research on knowledge, attitude, and practice related to diabetes in the general population in Galle District in Southern Sri Lanka showed that $77 \%$ of the respondents had a moderate level of knowledge about diabetes, $88 \%$ of the respondents attitude were still in bad, and $55 \%$ of the practice of the respondents were not involved in preventing of diabetes [6]. Different result on the other previous study showed that family history of suffering T2DM affects a person's behavior with better knowledge $(78.3 \%)$ and practice $(67.3 \%)$ compared to individuals who do not have T2DM family members $(54.5 \%$ and $36.3 \%$, respectively) [7]. The 
other previous study showed that had a family history of suffering T2DM was associated with regular exercise, limiting sugar intake, and routine blood glucose checks compared to respondents who did not [8].

Based on the description above, the researchers are interested in conducting research to find out (1) family history of T2DM in Universitas Sumatera Utara medical students, (2) the level of knowledge of Universitas Sumatera Utara medical students about T2DM, (3) the level of attitude of Universitas Sumatera Utara medical students towards T2DM, (4) the level of practice of Universitas Sumatera Utara medical students on T2DM, and (5) the relationship between family history of T2DM and knowledge, attitude, and practice toward T2DM among medical students in Universitas Sumatera Utara.

\section{Materials and Methods}

\section{Study design}

The study was conducted after obtaining approval from the Research Ethics Commission of the Universitas SumateraUtara No. 207/KEP/USU/2020. This study was a cross-sectional online questionnaire-based study. The study was conducted in April-October 2020. Research respondents were Universitas Sumatera Utara medical student's batches of 2017, 2018, and 2019 with inclusion criteria, namely, both male and female medical students at Universitas Sumatera Utara, not suffering from T2DM, willing to become research respondents by filling out questionnaires and signing informed consent. Respondents were excluded if they did not complete the questionnaire.

Informed consent statement was entered at the start of the questionnaire with a brief description of the aims and benefits of the study. Respondents were asked to sign consent for their participation in this study. The questions on the questionnaire consisted of respondent characteristics (name, gender, age, and class), family history of suffering T2DM and questions from three domains of behavior, namely, knowledge, attitude, and practice.

\section{Questionnaire}

The questions on the behavioral questionnaire, namely, domain knowledge, attitude, and practice were adapted from previous research questionnaires that had been tested for their validity and reliability [9].

1. Questions evaluating knowledge of T2DM were ten questions about everything that respondents know about T2DM. Selection of correct answers is given a value of 1 , while wrong answers are given a value of 0 . The total score is 10 . Interpretation of the results: Knowledge is good if the respondent gets the right answer with a score of $\geq$ mean value, while knowledge is lacking if the respondent gets a score < mean value.

2. The attitude toward T2DM, in this study, is the response or reaction of respondents regarding the prevention or management of T2DM. There are ten statements in the attitude domain which are grouped as positive statements (No. 3, 4, $6,8,9$, and 10) given a score of $4,3,2$, and 1 , and negative statements (No. 1, 2, 5, and 7 ) are scored 1, 2, 3, and 4 for each answer strongly agree, agree, disagree, and strongly disagree with the statement.

The total score in the attitude domain is 40 . Interpretation of the results: Good attitude if the respondent gets the right answer with a score $\geq$ mean value, while the attitude is less if the respondent gets a score < mean value.

3. The practice domain contains seven questions about what the respondent has done related to prevention or management of T2DM. Selection of the correct answer is given a value of 1 , while the wrong answer is given a value of 0 . Interpretation of the results: It is good if the respondent gets the right answer with a score $\geq$ mean value, while the practice is less if the respondent gets a score $<$ mean value.

\section{Statistical methods}

The statistical analysis was made using SPSS version 24. Data on family history of suffering T2DM and behavior toward T2DM are presented based on frequencies and means were used as descriptive statistics. The relationships between family history of T2DM and knowledge, attitude, and practice toward T2DM were analyzed using the Chi-square test, to assess the $p$ value $(p<0.05)$ and the prevalence ratio $(\mathrm{PR}>1)$ at $95 \% \mathrm{Cl}$.

\section{Results}

Three hundred and seventy Universitas Sumatera Utara medical students were participated in this study. The characteristics of 370 Universitas Sumatera Utara medical students batches of 2017, 2018, and 2019 were 233 females (63\%), 137 males (37\%), and the highest age was in the range of 20-25 years, namely, 232 people (62.7\%). Based on the batch category, it can be seen that the most respondents came from the 2018 batch, as many as 138 students (37.3\%) (Table 1).

Table 2 shows the percentage of 2017 , 2018, and 2019 Universitas Sumatera Utara medical 
Table 1: Characteristics distribution of respondents

\begin{tabular}{lll}
\hline Characteristics & $\mathrm{n}$ & $\%$ \\
\hline Gender & & \\
$\quad$ Female & 233 & 63.0 \\
$\quad$ Male & 137 & 37.0 \\
Age (years) & & \\
$18-19$ & 138 & 37.3 \\
$20-25$ & 232 & 62.7 \\
Batch & & \\
2017 & 137 & 37.0 \\
2018 & 138 & 37.3 \\
2019 & 95 & 25.7 \\
\hline
\end{tabular}

students who correctly answered the knowledge domain question. In this study, the results showed that the knowledge domain questions, number: 1, 2, 5, 6, and 9 were questions with a high percentage of being answered correctly by respondents (99.2\%, 99.5\%, $99.2 \%, 99.7 \%$, and $97.0 \%$, respectively).

Table 2: Mean and percentage of correct answer score on knowledge about T2DM

\begin{tabular}{|c|c|c|c|c|}
\hline No. & Questions & Mean & $\mathrm{n}$ & $\%$ \\
\hline 1. & $\begin{array}{l}\text { T2DM is a disease with symptoms of an increase in blood } \\
\text { glucose levels above normal limits. }\end{array}$ & 0.99 & 367 & 99.2 \\
\hline 2. & $\begin{array}{l}\text { The complaints felt by T2DM sufferers are easy hunger, } \\
\text { thirst, and frequent urination at night every day. }\end{array}$ & 0.99 & 368 & 99.5 \\
\hline 3. & $\begin{array}{l}\text { Exercise in people with T2DM should be done before } \\
\text { eating. }\end{array}$ & 0.53 & 195 & 52.7 \\
\hline 4. & $\begin{array}{l}\text { T2DM sufferers do not need to abstain from eating fried } \\
\text { foods, sausages, and canned food, but the amount is } \\
\text { limited. }\end{array}$ & 0.29 & 108 & 29.2 \\
\hline 5. & T2DM can affect all ages and genders. & 0.99 & 367 & 99.2 \\
\hline 6. & Complications can arise if I can't adjust my diet. & 1.00 & 369 & 99.7 \\
\hline 7. & $\begin{array}{l}\text { T2DM sufferers are unlikely to experience a drastic drop } \\
\text { in blood glucose levels. }\end{array}$ & 0.68 & 252 & 68.1 \\
\hline 8. & $\begin{array}{l}\text { T2DM disease can be cured by not consuming sweet } \\
\text { foods/drinks at all. }\end{array}$ & 0.16 & 59 & 15.9 \\
\hline 9. & $\begin{array}{l}\text { T2DM sufferers can still carry out work activities if they } \\
\text { continue to take medication regularly. }\end{array}$ & 0.97 & 359 & 97.0 \\
\hline 10. & $\begin{array}{l}\text { Consuming soft drinks, sugary foods, and syrups are not } \\
\text { factors that can increase blood glucose levels. }\end{array}$ & 0.78 & 289 & 78.1 \\
\hline \multicolumn{2}{|c|}{ Total mean } & 7.39 & & \\
\hline
\end{tabular}

From 370 respondent's answers to ten knowledge domain questions, mean value of correct answers of respondents was 7.39 of the total score 10. Based on knowledge scoring, it was shown that $50.8 \%$ of Universitas Sumatera Utara medical student's batches of 2017, 2018, and 2019 have good knowledge (Table 3).

Table 3: Category of respondents' knowledge about Type 2 diabetes mellitus

\begin{tabular}{lll}
\hline Category & Frequency $(\mathrm{n})$ & Percentage $(\%)$ \\
\hline Good & 188 & 50.8 \\
Poor & 182 & 49.2 \\
Total & 370 & 100 \\
\hline
\end{tabular}

In Table 4, the results of the answers of Universitas Sumatera Utara medical student's batches of 2017,2018 , and 2019 are shown regarding attitude domain questions which are divided into positive and negative questions.

In Table 4, it is found that respondents with the answers "strongly agree" and "agree" to negative statements, number: $1,2,5$, and 7 still have high scores with percentages of $58.4 \%, 59.4 \%, 60.6 \%$, and $92.7 \%$, respectively.

From the results of 370 respondent's answers to ten attitudes domain statements toward T2DM, the mean value is 28.87 of the total score 40 . The attitudes of respondents in this study were classified as good as much as $53.5 \%$, and less as much as $46.5 \%$ (Table 5).

Table 5: Category of respondents' attitude toward Type 2 diabetes mellitus

\begin{tabular}{lll}
\hline Category & Frequency $(\mathrm{n})$ & Percentage $(\%)$ \\
\hline Good & 198 & 53.5 \\
Poor & 172 & 46.5 \\
Total & 370 & 100 \\
\hline
\end{tabular}

In this study, we found that practice domain questions, number: 5 and 7 were questions with very low percentages of being answered correctly by the respondent $(12.4 \%, 99.5 \%$, and $12.2 \%$, respectively) (Table 6).

From 370 students who answered six questions on practice domain, mean value of the correct answers of respondents was 2.48 of the total score 7 . Based on the practice scoring, $52.2 \%$ of Universitas Sumatera Utara medical students batches of 2017, 2018, and 2019 have less practice (Table 7).

Based on Table 8, it can be known that of 370 Universitas Sumatera Utara medical students were being respondents in this study, 197 people (53.2\%) have a family history of suffering T2DM and 173 people $(46.8 \%)$ respondents who did not have.

The results of analysis of the relationship between family history of T2DM and knowledge, attitude, and practice regarding T2DM among medical students are shown in Table 9.

This study was found that the percentage of knowledge in good category, the attitude in good category, and the practice in good category for T2DM to respondents who have a family history of T2DM were higher than those who did not have (58\% vs. $42 \%$; $60 \%$ vs. $40 \%$; and $56 \%$ vs. $44 \%$ ). Chi-square test showed that there was a significant relationship between having a family history and knowledge of T2DM $(p=0.002, R P=1.921,95 \% \mathrm{Cl}=1.270-2.906)$,

Table 4: Mean and percentage of correct answer score on attitude toward T2DM

\begin{tabular}{|c|c|c|c|c|}
\hline No. & Questions & Mean & $\mathrm{n}$ & $\%$ \\
\hline 1. & I prefer to eat sweet foods. & 2.61 & 216 & 58.4 \\
\hline 2. & I prefer to eat instant noodles than eat vegetables. & 2.68 & 220 & 59.4 \\
\hline 3. & If I have T2DM, I still take medicine as recommended by the doctor even though my body feels comfort. & 3.10 & 315 & 85.2 \\
\hline 4. & If I suffer from T2DM, I feel more secure if I take T2DM medicine together with herbal medicine. & 2.02 & 58 & 15.7 \\
\hline 5. & If have T2DM, I feel the oral drug T2DM is more effective at lowering glucose levels than the insulin injection drug. & 2.62 & 224 & 60.6 \\
\hline 6. & I prefer regular moderate exercise to strenuous but irregular exercise. & 3.50 & 363 & 98.1 \\
\hline 7. & I don't feel the need to have my eye health checked. & 3.16 & 343 & 92.7 \\
\hline 8. & I still need to do a urine test even though I have done a blood test to find out the blood glucose level. & 2.79 & 268 & 72.4 \\
\hline 9. & I feel it is my duty to check and clean my feet every day when I take a bath. & 3.40 & 359 & 97.0 \\
\hline 10. & If I have T2DM, I prefer to soak my feet in warm water instead of using a hot bottle to warm my feet. & 2.99 & 314 & 84.8 \\
\hline Total mean & & 28.87 & & \\
\hline
\end{tabular}


Table 6: Mean and percentage of correct answer score on practice toward T2DM

\begin{tabular}{|c|c|c|c|c|}
\hline No. & Questions & Mean & $\mathrm{N}$ & $\%$ \\
\hline 1. & Have you had a blood pressure check? & 0.68 & 253 & 68.4 \\
\hline 2. & Have you ever had a urine pressure test? & 0.17 & 64 & 17.3 \\
\hline 3. & Do you exercise regularly? & 0.54 & 199 & 53.8 \\
\hline 4. & If one of your parents had diabetes, would you avoid foods that contain lots of sugar and fat? & 0.77 & 284 & 76.8 \\
\hline 5. & Have you ever participated in a diet regimen for preventing T2DM? & 0.12 & 46 & 12.4 \\
\hline 6. & Do you always count the calories of the food you will consume? & 0.19 & 71 & 19.2 \\
\hline 7. & Do you always control your blood glucose levels or go to the doctor even though you feeling well? & 0.12 & 45 & 12.2 \\
\hline Total mean & & 2.48 & & \\
\hline
\end{tabular}

T2DM: Type 2 diabetes mellitus

Table 7: Category of respondents' practice toward Type 2 diabetes mellitus

\begin{tabular}{lll}
\hline Category & Frequency $(\mathrm{n})$ & Percentage $(\%)$ \\
\hline Good & 177 & 47.8 \\
Poor & 193 & 52.2 \\
Total & 370 & 100 \\
\hline
\end{tabular}

attitudes $(p=0.005, \mathrm{RP}=1.815,95 \% \mathrm{Cl}=1.200$ $2.745)$, and practice $(p=0.001, R P=2.092,95 \% \mathrm{Cl}=$ 1.380-3.173) (Table 9). The existence of a family

Table 8: Distribution of family history of T2DM among Universitas Sumatera Utara medical students batches of 2017 , 2018, and 2019

\begin{tabular}{lll}
\hline Family history of T2DM & $\mathrm{N}$ & $\%$ \\
\hline Yes & 197 & 53.2 \\
No & 173 & 46.8 \\
Total & 370 & 100 \\
\hline T2DM: Type 2 diabetes mellitus & &
\end{tabular}

history of suffering T2DM affected knowledge, attitude, and practice toward T2DM by 1.921 times, 1.815 times, and 2.092 times compared to having no.

Table 9: Family history of T2DM and knowledge, attitude, and practice regarding T2DM among medical students

\begin{tabular}{|c|c|c|c|c|c|c|}
\hline \multirow[t]{2}{*}{ Behavior } & \multicolumn{2}{|c|}{ Family history of T2DM } & \multirow[t]{2}{*}{$p$ value } & \multirow[t]{2}{*}{ PR } & \multicolumn{2}{|c|}{$95 \% \mathrm{Cl}$} \\
\hline & Yes (\%) & No (\%) & & & Lower & Upper \\
\hline \multicolumn{7}{|c|}{ Knowledge } \\
\hline Good & $115(58)$ & $73(42)$ & 0.002 & 1.921 & 1.270 & 2.906 \\
\hline Poor & $82(42)$ & $100(58)$ & & & & \\
\hline \multicolumn{7}{|l|}{ Attitude } \\
\hline Good & $119(60)$ & $79(46)$ & 0.005 & 1.815 & 1.200 & 2.745 \\
\hline Poor & $78(40)$ & $94(54)$ & & & & \\
\hline \multicolumn{7}{|l|}{ Practice } \\
\hline Good & $111(56)$ & $66(38)$ & 0.001 & 2.092 & 1.380 & 3.173 \\
\hline Poor & $86(44)$ & $107(62)$ & & & & \\
\hline
\end{tabular}

\section{Discussion}

T2DM is a disease of metabolism disorders with a high prevalence in various countries in the world. T2DM is one of the top ten causes of death globally worldwide, along with other non-communicable diseases [1]. There was various studies have been conducted to determine the factors that increase the risk of developing T2DM. Knowledge, attitude, and practice toward T2DM are known to predispose individuals to suffer from T2DM [10], [11]. In this study, it was found that the results of the analysis of respondents behavior toward T2DM showed good categories with high percentages in the domain of knowledge and attitude, but not in practice $(50.8 \%, 53.5 \%$, and $47.8 \%$, respectively).
The results of this study are the same as the results of the previous studies showing about half of the participants $(53.3 \%)$ had good knowledge scores and $46.3 \%$ of participants had positive attitude toward diabetes [12]. The another previous study on the population in South East Ethiopia showed that 52.5\% of participants were knowledgeable and $55.9 \%$ had a good attitude towards T2DM. But different to the results of the current study, a previous study in South East Ethiopia showed that the domination of practice against diabetes showed a high percentage of good (56.6\%) [13] and the other previous study show level of knowledge, attitude, and practice of diabetes is very poor [14]. The difference between the results of the current study and the results of the previous studies may also be due to the selection of respondents who differ in age ranges, demographics, and educational status.

Behavior is an activity or activity which is the result of human experience and interaction with the environment which is manifested in the form of knowledge, attitude, and practice. Human behavior is a reaction that can be simple or complex, influenced by age, gender, ethnicity, education, and socioeconomics. Knowledge or cognitive is an important domain for the formation of a person's attitude. Attitude is a reaction or response that is still closed from someone to a stimulus or object. An attitude has not been automatically manifested in an action. To turn an attitude into a real action, a supporting factor or a condition is needed, namely an enabling factor, such as the physical environment, available, or unavailable facilities and so on [5]. The physical environment of infrastructure and facilities surrounding the current research respondents may be the reason for the high percentage of categories both in the knowledge and attitude domains that are not in line with the practice domain.

Knowledge, attitude, and practice can be formed by learning, one of which is using a model. Children will perform behavior similar to their parents' behavior [5]. Having a family with a history of suffering T2DM can affect the knowledge, attitude, and practice of children toward T2DM. Having a family history of suffering T2DM is a risk factor for T2DM disease [6], [15]. In this study, it was known that out of 370 Universitas Sumatera Utara medical students who became respondents, 197 people $(53.2 \%)$ have a family history of T2DM.

There is a significant relationship between having a family history of T2DM with behavior toward T2DM. The existence of a family history of suffering from T2DM affected knowledge, attitude, and practice 
toward T2DM by 1.921 times, 1.815 times, and 2.092 times compared to having no. The previous studies have found similar results, namely, populations who have a family history of suffering T2DM have better knowledge, awareness, and practice against T2DM disease [7], [16], [17]. However, the other previous study shows different results, namely, having a family history of T2DM affects only the respondents' awareness of T2DM not on the respondents' knowledge and attitudes [13].

Having one or more family backgrounds or parents who suffer from T2DM will increase the chance of incidence 2-6 times greater than experiencing T2DM. A person with a family history of T2DM has a risk of developing T2DM in old age, and the chances are greater if the parents also suffer from T2DM disease. Family history of T2DM is an unmodifiable risk factor. If one parent is exposed to T2DM, the risk of getting T2DM is 3.4-3.5 times and if both parents have T2DM, the risk of having T2DM is 6.1 times [18], [19]. Although family history is an unmodifiable risk factor for developing T2DM, the presence of this family history plays a role in the development of behavior towards T2DM and this behavior can be modified.

\section{Conclusion}

This study shows that students have good knowledge and attitude toward T2DM but not in line with practice. Having a family history of T2DM is a factor that influences knowledge, attitudes, and practice toward T2DM among medical students at the Universitas Sumatera Utara. Further research is needed to assess the role of the physical environment, infrastructure, and facilities that influence respondents in practice on T2DM. Further research is also needed to analyze how the socioeconomic and cultural roles in families with a family history of T2DM and behavior of respondents toward T2DM.

\section{Acknowledgments}

We would like to thank, Dean Faculty of Medicine at the Universitas Sumatera Utara who has provided the means for implementation of this research. We also thank all the respondents for spending their valuable time to answer the questions.

\section{References}

1. Saeedi P, Salpea P, Karuranga S, Petersohn I, Malanda B, Gregg EW, et al. Mortality attributable to diabetes in 20-79 years old adults, 2019 estimates: Results from the international diabetes federation diabetes atlas, $9^{\text {th }}$ edition. Diabetes Res Clin Pract. 2020;162:108086. https://doi.org/10.1016/j. diabres.2020.108086

PMid:32068099

2. World Health Organization. Global Report on Diabetes. Geneva: World Health Organization; 2016. Available from: https://www. who.int/publications/i/item/9789241565257. [Last accessed on 2020 Jul 10].

3. Powers AC. Diabetes Mellitus, Obesity, Lipoprotein Metabolisms in Harrison's Endocrinology. $4^{\text {th }}$ ed. New York: McGraw-Hill Education; 2017. p. 280-291.

4. Perkumpulan Endokrinologi Indonesia (Perkeni). Konsensus Pengelolaan dan Pencegahan Diabetes Melitus Tipe 2 di Indonesia 2015. Pengurus Besar Perkumpulan Endokrinologi Indonesia (PB Perkeni). The Indonesian Association of Endocrinologists.Consensus for the Management and Prevention of Type 2 Diabetes Mellitus in Indonesia 2015. Executive Board of the Indonesian Endocrinology Association; 2015. Available from: https://www.pbperkeni. or.id/wp-content/uploads/2019/01/4.-Konsensus-Pengelolaandan-Pencegahan-Diabetes-melitus-tipe-2-di-IndonesiaPERKENI-2015.pdf. https://doi.org/10.23886/ejki.3.4810. [Last accessed on 2020 Jul 10].

5. Notoadmojo, S. Promosi Kesehatan dan Perilaku Kesehatan (Health Promotion and Health Behavior). Jakarta: PT Rineka Cipta; 2014. p. 15-8, 146. https://doi.org/10.47034/ppk.v2i2

6. Herath HM, Weerasinghe NP, Dias H, Weerarathna TP. Knowledge, attitude and practice related to diabetes mellitus among the general public ingalle district in Southern Sri Lanka: A pilot study. BMC Public Health. 2017;17:535. https://doi. org/10.1186/s12889-017-4459-5

PMid:28571566

7. Wolde M, Berhe N, Die IV, Medhin G, Tsegaye A. Knowledge and practice on prevention of diabetes mellitus among diabetes mellitus family members, in Suburban cities in Ethiopia. BMC Res Notes. 2017;10:551. https://doi.org/10.1186/ s13104-017-2871-7

PMid:29096704

8. Donny A, Naa-Solo T, Shinga F. The influence of family history of Type 2 diabetes mellitus on positive health behavior changes among African americans. Int J Chronic Dis. 2020;2020:8016542. PMid:32090059

9. Hartini S. Tingkat Pengetahuan, Sikap, dan Tindakan Masyarakat Kecamatan Tanjung Tiram tentang Diabetes Melitus' Assessment of Knowledge, Attitude, and Practice of the Community of Tanjung Tiram Subdistrict on Diabetes Mellitus; 2017. Available from: http://www.repositori.usu.ac.id/ handle/123456789/4538. [Last accessed on 2020 Jul 15].

10. Tabák AG, Herder C, Rathmann W, Brunner EJ, Kivimäki M Prediabetes: A high-risk state for diabetes development. Lancet. 2012;379:2279-90. https://doi.org/10.1016/ s0140-6736(12)60283-9

PMid:22683128

11. Mumu JS, Saleh F, Ara F, Haque RM, Ali L. Awareness regarding risk factors of Type 2 diabetes among individuals attending a tertiary-care hospital in Bangladesh: A crosssectional study. BMC Res Notes. 2014;7:599. https://doi. org/10.1186/1756-0500-7-599

PMid:25187113

12. Alsous M, Jalil MA, Odeh M, Al Kurdi R, Alnan M. Public knowledge, attitudes and practices toward diabetes mellitus: A crosssectional study from Jordan. PLoS One. 2019;14(3):e0214479. https://doi.org/10.1371/journal. pone.0214479

PMid:30925187 
13. Kassahun CW, Mekonen AG. Knowledge, attitude, practices and their associated factors towards diabetes mellitus among non diabetes community members of Bale Zone administrative towns, South East Ethiopia. A crosssectional study. PLoS One. 2017;12(2):e0170040. https://doi.org/10.1371/journal. pone. 0170040

PMid:28152066

14. Daba A, Yazew T. Associated factors with knowledge, attitude and practices of Type II diabetic patients in Ambo university referral hospital, Ethiopia. Am J Lab Med. 2020;5(4):102-12. https://doi.org/10.11648/j.ajlm.20200504.14

15. Powers AC. Diabetes mellitus. In: Longo DL, Kasper DL, Jameson JL, Fauci AS, Hauser SL, Loscalzo J, editors. Harrison's Endocrinology. $3^{\text {rd }}$ ed. United States: McGraw-Hill Education; 2013. p. 261-307.

16. Jaesung C, Ji-Yeob C, Sang-Ah L, Kyoung-Mu LAesun S, Juhwan
$\mathrm{O}$, et al. Association between family history of diabetes and clusters of adherence to healthy behaviors. Br Med J. 2019;9(6):3-11.

17. Choi J, Choi J, Lee S, Lee KM, Shin A, Oh J, et al. Association between family history of diabetes and clusters of adherence to healthy behaviors: Cross-sectional results from the health examinees-gem (HEXA-G) study. BMJ Open. 2019;9:e025477. https://doi.org/10.1136/bmjopen-2018-025477

PMid:31209083

18. Harrison TA, Hindorff LA, Kim H, Wines RC, Bowen DJ, McGrath BB, et al. Family history of diabetes as a potential public health tool. Am J Prev Med. 2003;24(2):152-9. PMid: 12568821

19. Meigs JB, Cupples LA, Wilson PW. Parental transmission of Type 2 diabetes: The Framingham offspring study. Diabetes. 2000;49:2201-7. https://doi.org/10.2337/diabetes.49.12.2201 PMid:11118026 